Acest articol se citează:

Ursu, V. A., (2015/2018). O perspectivă socială a stării de bine: emergența eudaimoniei și a scopului în viața în mediul organizațional.

Studia Doctoralia. Psychology and Educational Science, 9-10, 55-71.

\title{
O PERSPECTIVĂ SOCIALĂ A STĂRII DE BINE: EMERGENȚA EUDAIMONIEI ȘI A SCOPULUI ÎN VIAṬA ÎN MEDIUL ORGANIZAT,IONAL
}

Vlad Adrian Ursu, Universitatea din București, Facultatea de Psihologie și Științele Educației.

E-mail: ursuvladadrian@gmail.com

\begin{abstract}
This paper aims to investigate the psychological well-being in relation to group socio-cognitive factors at work. Data was collected on a sample of 133 participants that were employed and had a manager at the time of filling in the scales. The results support the mediation role of trust between transformational and organizational identification. Organizational identification totally mediated the relationship between transformational leadership and psychological well being and its subscales: purpose in life, positive relationships with others, environmental control. The relationship between transformational leadership and self acceptance, personal growth and positive relations with other was mediated by the trust in coworkers.
\end{abstract}

Keywords: Psychological wellbeing, transformational leadership, trust in coworkers, organizational identification.

\section{Introducere}

Această lucrare dorește să investigheze impactul aspectelor social-cognitive de la locul de muncă asupra stării psihologică de bine generale a angajaților. În primul rând, îşi propune să determine valoarea predictivă a leadershipul transformațional și încrederea cu colegii asupra identificării cu organizația, iar în al doilea rând doreşte să stabilească mecanismele prin care încrederea cu colegii şi leadershipul transformațional prezic starea de bine psihologică, relație cel mai probabil mediată de identificarea cu organizația.

Mai jos descriem principalele constructe analizate în cadrul acestui articol: 


\section{Starea de bine psihologică}

Starea de bine este tratată în două mari paradigme: hedonică și eudaimonică. Paradigma hedonica pune accentul pe plăcere şi dorinţe şi este măsurată prin emoţiile pozitive raportate la emoţiile negative şi satisfacția legată de viață (Ryan \& Deci, 2001). Paradigma eudaimonică porneşte de la Aristotel şi este introdusă în psihologie prin paradigma umanistă de către A. Maslow, prin autoactualizarea, şi de către C. Rogers, prin tendinţa individului de a atinge sinele ideal si a deveni o persoană pe deplin funcțională (David și Aurora, 2017, p. 40-41). Astfel, starea de bine psihologică face referire la „efortul de a atinge perfecțiunea, adică de realizarea adevăratului potenţial al persoanei" (Ryff \& Keyes, 1995, p. 100). Succesul adaptării individului la mediul, exprimată prin starea de bine psihologică, este surprinsă prin şase factori (Ryff, 1989):

Autoacceptarea se referă la prezența unor atitudini pozitive îndreptate către sine; conştientizarea şi acceptarea aspectelor multiple referitoare la sine fie ele bune sau rele; sentimente pozitive referitoare la trecutul propriu.

Relațiile pozitive $\mathrm{cu}$ ceilalți se referă la prezența unor relaţii calde, satisfăcătoare şi de încredere cu ceilalţi; îngrijorarea cu privire la bunăstarea celorlalţi; a fi capabil de empatie, afecţiune şi intimitate puternică; înţelegerea beneficiilor şi costurilor în relaţiile umane.

Autonomia se referă la a fi autodeterminat şi independent; a fi rezistent la presiunile sociale $\mathrm{cu}$ privire a credinţele şi comportamentele proprii; reglarea comportamentală la propria iniţiativa; evaluarea sinelui în raport cu standarde personale.

Controlul asupra mediului se referă la a avea un sentiment de măiestrie şi competenţă în gestionarea mediului; a controla o plajă largă de activități externe; a pune în valoare oportunitățile din jur; capacitatea de a alege şi influența contexte favorabile pentru nevoile şi valorile proprii.

Sensul în viață sau scopul în viață se referă la a avea țeluri în viață şi un sens a unei direcţii clare; a simţi că există sens în viaţa prezentă şi trecută; păstrarea credinţelor care oferă vieţii un scop; are ţeluri şi scopuri pentru care trăieşte. 
Dezvoltarea personală se referă la a avea un sentiment de dezvoltare continuă; îşi defineşte sinele ca fiind într-o continuă dezvoltare şi expansiune; este deschis către experienţe noi; are un sentiment de realizare a potenţialului propriu; percepe îmbunătăţiri în timp ale sinelui şi ale comportamentelor proprii; este adaptabil în aşa fel încât să reflecte mai multă eficacitate şi cunoştințe legate de sine.

Astfel, putem observa faptul că atitudinile cu privire la sine, la interacțiunea sinelui cu ceilalţi, şi cu mediul pot fi surse ale unei stări de bine psihologice. Mai mult decât atât, asumarea şi integrarea unui rol social în identitatea cel mai probabil duce la formarea unui sens şi a unei semnificații în viaţă (Thoits, 2012).

O cercetare inovativă (Ryff, Singer \& Love, 2004) arată faptul că angajații care au o stare de bine psihologică ridicată au prezentat niveluri mai scăzute de cortizol, niveluri mai scăzute de citokine proinflamatorii, niveluri scăzute de riscuri cardiovasculare şi durate mai mare ale somnului REM (markeri pentru depresie) comparativ cu scorurile mici ale stării de bine psihologice şi ale stării de bine hedonice (subiective) care au avut un efect minimal. Astfel, starea psihologică de bine poate fi văzută de către organizații precum un combustibil pentru productivitatea de la locul de muncă, precum un factor protectiv la stres şi precum o pregătirea de adaptare la schimbările şi presiunile din mediu.

Deşi starea de bine psihologică a fost asociată cu multe rezultate pozitive cu privire la sănătatea individului şi, prin definiţie, prosperitatea acestuia, puține cercetări au investigat acest construct în relaţie cu munca.

\section{Leadership transformațional}

Leadershipul transformațional trece dincolo de relațiile de tipul tranzacţional şi se axează pe motivarea celorlalţi pentru a ajunge la performanțe mai mari decât aceştia credeau că ar fi posibil (Bass, 1998; Bass \& Riggio, 2006). Importanța leadershipului transformațional este dată de aducerea în prim plan al misiunii şi valorilor organizației pentru subordonaţi, fiind esențial în comunicarea organizațională în diferitele niveluri ierarhice, dând naştere unui scop comun. „Recompensele devin astfel interne, rezultând din realizarea obiectivelor şi autoactualizare, 
mai degrabă decât externe, bazate pe aspecte materiale" (David \& Aurora, 2017, p. 293).

În literatură există mecanismele mediatoare prin care leadershipul transformațional poate avea un impact asupra stări de bine psihologică. Acestea sunt: semnificaţia muncii dată de către angajat (Arnold, Turner, Barling, Kelloway, \& McKee, 2007), încrederea în leader (Kelloway, Turner, Barling \& Loughlin, 2012) şi autoeficacitatea (Nielsen, Yarker, Randall \& Munir 2009). Aceste variabile se îndepărtează de teoria socială a leadershipului, axându-se mai mult pe aspecte cognitive care sunt mai dificil de stabilit ca obiect al intervenţiei organizaţionale şi care pot fi surprinse de către un factor supraordonat: identificarea cu organizaţia. Multe cercetări indică faptul că leadershipul transformațional este asociat nivele crescute de efort suplimentar, implicarea în muncă şi comportament civic organizaţional (Howell și Higgins 1990; Jung, Chow \& Wu. 2003; Koh, Steers, \& Terborg, 1995; Podsakoff, MacKenzie, Moorman \& Fetter 1990) ce pot surpinde factori ai stării de bine psihologice precum dezvoltarea personală datorită implicării şi a efortului şi relaţiilor pozitive cu ceilalţi datorită comportamentelor de tip prosocial/civic.

\section{Identificarea cu organizaţia}

Apelând la teoria socială a identităţii, care postulează faptul că în multe contexte sociale, oameni îşi definesc un concept de sine în raport cu grupul de apartenența, individul este deseori dependent din punct de vedere psihologic de starea grupului raportat la context şi excluderea lui din acesta este privită devastatoare, mai ales dacă grupul oferea individului un sentiment de stabilitate, sens, scop şi direcţie (Haslam, S., Jetten, Postmes, \& Haslam, 2009).

Teoria categorizării sinelui (Turner, Hogg, Oakes, Reicher \& Wetherell, 1987) extinde repertoriul explicativ al teoriei sociale a identitătii, deoarece priveşte identitatea individului categorizată la diferite niveluri de abstractizare, mai exact, individul se poate categoriza la un grad de abstractizare scăzut „eu”, la unul mare de abstractizare „noi ca organizație” şi cel mai mare grad de abstractizare „noi” ca specie umană. Relevant pentru lucrarea de faţă este faptul că organizațiile pot oferi, prin incluziunea individului în categoria identitară a organizației, 
repere prin care individul îs poate extinde perspectiva prin care se caracterizează, fie prin succesul grupului, fie prin misiunea organizaţiei de a aduce o valoare adăugată societății per total.

Ashforth, Harrison și Corley (2008) oferă patru motive solide pentru care organizațiile sunt importante. În primul rând stau la baza formării identităţi sociale ceea ce implică ca oamenii să se definească pe ei înşişi, să facă sens de locul în această lume precum şi să se navigheze în această. În al doilea rând, este o nevoie fundamentală că omul să se indentifică cu şi să se simtă parte dintr-un grup mai mare. Organizaţiile satisfac această nevoie precum şi nevoia pentru o stima de sine robustă. În al treilea rând, identificarea cu organizația este asociată cu mai multe rezultate importante pentru organizații, incluzând satisfacția angajaţilor, performanța şi retenţia. Deşi în studiile recente a început să se exploreze aspecte negative a identificării cu organizaţia, precum reducerea creativităţii şi rezistenței la schimbare (datorită efectului de grouthink şi conformitate), dacă leadershipul este unul de tip transformaţional, considerăm acest posibil efect negativ ca fiind minimal. În ultimul rând identificarea cu organizația a fost relaţionata cu leadershipul, percepția justiţiei şi semnificaţia în muncă

În final organizațiile pot oferi indivizilor un sens, scop şi un sentiment de apartenența prin misiunea, valorile şi colectivul de muncă, integrate în identitatea individului dacă acesta se identifică cu particularitățile organizației. Acest fapt are potențialul de a-i oferi individului beneficii generale pe factorii stării de bine psihologice precum: relații pozitive cu ceilalți (apartenență), scop în viață (integrarea misiunii şi valorilor organizaţionale), dezvoltare personală (prin efortul şi muncă suplimentară depusă odată cu identificarea cu organizația).

\section{Încrederea în colegii de muncă}

Relaţiile de colegialitate în organizaţii sunt unice în mediul organizaţional din prisma faptului că acestea nu sunt influenţate de balanţă de putere, fiind în principiu egale. Importanța dată pentru lucrarea de faţă este că sentimentul de apartenența la un grup restrâns este greu să fie constituit dacă analizăm relațiile ierarhice care au tendinţa de a formaliza interacţiunea între membrii grupului şi de a o normaliza într-o direcție în care subordonații să nu aibă un imput major 
în definirea lui. Astfel, cele mai simple dar în acelaşi timp cele mai puternice surse ale sentimentului de apartenența este familia, care, chiar dacă are un lider emergent („cap de familie”), acesta are mai mult funcție de a susţine dinamica şi de o orienta, mai degrabă decât de a asigura o interacțiune calitativă în funcţie de rolurile pe care membri grupului îl ocupă. Sumarizând, colegii de muncă sunt importanţi deoarece aceştia formează rețele sociale emergente informale în organizații care sunt caracterizate de un schimb de informații orizontal mai eficiente comparativ cu rețelele formale.

Încrederea poate fi conceptualizat atât ca factor de personalitate (Wrightsman, 1966; Rotter, 1967) cât şi ca factor situaţional, de expertiză şi de rol care modulează relația dintre indivizi (Zand, 1972). Relevând pentru contextul organizaţional Ferres, Connell, și Travaglione (2004) a arătat faptul că încrederea în colegii de muncă a fost asociată cu o percepție mai mare a suportului organizaţional, intenţii mai scăzute de turnover şi cu un mai mare angajament afectiv faţă de organizaţie. Lee și Stajkovic (2005) a arăta faptul că încrederea într-un membru specific al echipei a dus la o mai mare cooperare în acea echipă, cel mai probabil datorită capitalului social. Angajaţii sunt mai dispuşi să comunice ideile şi problemele referitoare la muncă colegilor comparativ cu cei care au responsabilitatea formală de a prelua acest tip de informație precum managerul sau departamentul de resurse umane (Stevenson \& Gilly, 1991).

În final, Tan şi Lim (2009) arată că încrederea cu organizaţia mediază parţial relaţia dintre încrederea în colegii de muncă şi efectele organizaţionale de angajament afectiv şi performanţă.

În economia acestui articol, vom prezenta ipotezele de cercetare odată cu rezultatele.

\section{Metodologie}

\section{Procedură si participanți}

Pentru stabilirea mărimea eşantionului minim pentru testarea ipotezelor formulate, s-a utilizat software-ul Gpower 3.0.10 (Faul, Erdfelder, Lang, \& Buchner, 2007) cu următorii parametrii setaţi: având în vedere faptul că relaţia de mediere implică regresii multiple, iar acest 
test este unul de tip F, s-a selectat în „Test Family” - „F test” cu testul statistic setat la "Multiple regression: Omnibus $\left(\mathrm{R}^{2}\right.$ deviation from zero)", „Squared multiple correlation $\mathrm{R}^{2 \prime}$ este setat la un $\mathrm{R}^{2}$ mediu de .09 ceea ce ne oferă o mărime a efectului „Effect size $\mathrm{f}^{2}=.098^{\prime \prime}, \alpha$ este setat la $.05, "$ Power $(1-\beta$ err prob $)=.80$ " iar numărul de predictori este setat la 3 deoarece avem 2 mediatori formulaţi în ipoteza 12 a studiului. Eşantionul minim recomandat pentru criteriile mai sus menţionate este de $\mathrm{N}=115$, cu un $\mathrm{F}$ critic $=2.68$.

Având în vedere ipotezele şi obiectivele cercetării, s-au recrutat participanţi la studiu pe baza unui eşantion de convenienţă, folosind platformele de socializare precum Linkedin şi Facebook. Considerând aspectul nonrestrictiv al ipotezelor, singurele condiţii pentru participare la studiu a fost că voluntarul să lucreze în momentul completării chestionarului şi să fie subordonat unui manager, coordonator sau mentor. În total, au fost colectate 133 de respondenţi cu vârste cuprinse între 19 şi 50 de ani $(\mathrm{M}=27.5, \mathrm{SD}=7.13)$, dintre care 89 sunt femei (68.5\%) şi 41 bărbaţi (31.5\%). 3 respondenţi au fost excluşi din baza de date pe baza scorurilor standard $\mathrm{Z}$ extreme pe care le-au prezentat (+/3SD). Eşantionul a fost cuprins dintr-o plajă largă de industrii şi vechime în muncă, incluzând şi angajaţi cu funţii de conducere dar şi doar de execuţie.

Pentru analizele statistice s a folosit SPSS 20 (IBM Corp, 2011) şi macroul PROCESS 2.16.3 (Hayes, 2016) conceptul special pentru analize de mediere şi moderare.

\section{Instrumente}

Leadershipul transformațional a fost măsurat folosind varianta tradusă a chestionarului de Leadership Transformațional (Rafferty \& Griffin, 2004), compus din 15 itemi măsurați pe o scală Likert în 5 trepte unde: 1 = Dezacord Puternic și 5 = Acord Puternic. În acest studiu, alpha Cronbach a fost de .92 .

Identificarea cu organizaţia a fost măsurat folosind varianta tradusă a chestionarului lui Cheney (1983), compus din 25 de itemi măsurați pe o scală Likert în 7 trepte unde $1=$ „Dezacord Puternic" și $7=$ „Acord Puternic". În acest studiu, alpha Cronbach a fost de 95. 
Încrederea cu colegii a fost măsurata folosind varianta tradusă al subfactorul "Încredere" al factorului Agreabilitate din NEO-PI-R (Iliescu, Popa \& Dimache, 2016), compus din 10 itemi măsuraţi pe o scală Likert în 5 trepte unde: $1=$ Dezacord Puternic și $5=$ Acord Puternic. În acest studiu, alpha Cronbach a fost de .87 pentru acest instrument.

Starea de bine psihologică a fost măsurata folosind varianta adaptată a Scalei de Stare de bine psihologică al lui Riff (Kállay şi Rus, 2014), compusă din 44 de itemi măsuraţi pe o scală scala Likert în 6 trepte unde: $1=$ „Dezacord Total” și $5=$ "Acord Total”. Scala este compusă din 6 factori: autonomie, controlul mediului, dezvoltare personală, reatii pozitive cu ceilalţi, scop în viaţă şi acceptare de sine/autoacceptare. În acest studiu, alpha Cronbach a fost de .94 pentru acest instrument.

\section{Rezultate și discuții}

Setul de date a fost complet, fără valori lipsă datorită administrării online cu răspunsuri obligatorii. Tabelul 1 prezintă mediile statisticile descriptive aferente datelor culese pentru acest studiu. Vârsta eşantionului este reprezentată de o medie mică raportată la populaţia generală din câmpul muncii.

Tabel 1. Statistici Descriptive

\begin{tabular}{|c|c|c|c|c|c|}
\hline & $\mathrm{N}$ & $\begin{array}{l}\text { Minimu } \\
\mathrm{m}\end{array}$ & $\begin{array}{l}\text { Maximu } \\
\mathrm{m}\end{array}$ & Media & $\begin{array}{l}\text { Abaterea } \\
\text { Standard }\end{array}$ \\
\hline Varstă în ani & 130 & 19.00 & 50.00 & 27.56 & 7.13 \\
\hline $\begin{array}{l}\text { Oameni în } \\
\text { subordine }\end{array}$ & 130 & .00 & 300.00 & 11.13 & 30.73 \\
\hline Leadership & 130 & 24.00 & 75.00 & 55.96 & 12.19 \\
\hline $\begin{array}{l}\text { Transformațional } \\
\text { Incredere cu } \\
\text { colegii }\end{array}$ & 130 & 22.00 & 50.00 & 39.79 & 6.35 \\
\hline $\begin{array}{l}\text { Identificare cu } \\
\text { organizația }\end{array}$ & 130 & 36.00 & 169.00 & 117.30 & 31.63 \\
\hline
\end{tabular}




\begin{tabular}{lccccc}
$\begin{array}{l}\text { Stare de bine } \\
\text { psihologică }\end{array}$ & 130 & 147.00 & 262.00 & 220.83 & 24.628 \\
Valid N (listwise) & 130 & & & & \\
\hline
\end{tabular}

Tabelul 2 prezintă indicii de aplatizare şi de distribuire a datelor. Toate variabilele măsurate prezintă indicatori în intervalul +/-1 ceea ce indică o distribuţie normală a datelor ceea ce ne permite rularea de statistici parametrici.

Tabel 2. Statistici distributie date

\begin{tabular}{lllll}
\hline & \multicolumn{2}{c}{ Skewness } & Kurtosis \\
\cline { 2 - 5 } & Statistic & Std. Error & Statistic & Std. Error \\
\hline Leadership & -.627 & .212 & -.451 & .422 \\
Transformațional & & & & \\
Incredere cu colegii & -.585 & .212 & .042 & .422 \\
Identificare cu & -.545 & .212 & -.373 & .422 \\
organizatia & & & & \\
Stare de bine & -.566 & .212 & -.131 & .422 \\
psihologica & & & & \\
Valid N (listwise) & & & & \\
\hline
\end{tabular}

Liniaritatea: Tabelul 3 prezintă indicii de corelaţie Pearson între variabilele specificate în ipoteze înaintate. Toate corelaţiile au fost semnificative la un prag de $\mathrm{p}<.01$. Leadershipul transformațional a corelat pozitiv cu încrederea în colegi $\left(\mathrm{R}^{2=} .17, \mathrm{p}<.01\right)$, cu identificarea $\mathrm{cu}$ organizaţia $\left(\mathrm{R}^{2=} .52, \mathrm{p}<.01\right)$ şi cu starea psihologică de bine $\left(\mathrm{R}^{2=} .06, \mathrm{p}<\right.$ $.01)$; Identificarea $\mathrm{cu}$ organizația a corelat pozitiv $\mathrm{cu}$ identificarea $\mathrm{cu}$ organizația $\left(\mathrm{R}^{2=} .22, \mathrm{p}<.01\right)$ şi starea de bine psihologică $\left(\mathrm{R}^{2=} .12, \mathrm{p}<.01\right)$.

Tabel 3. Tabel de corelații

\begin{tabular}{|c|c|c|c|c|}
\hline & Leadership & $\begin{array}{l}\text { Incredere } \\
\text { cu colegii }\end{array}$ & $\begin{array}{l}\text { Id. cu } \\
\text { organizat } \\
\text { ia }\end{array}$ & $\begin{array}{l}\text { Stare de } \\
\text { bine }\end{array}$ \\
\hline
\end{tabular}




\begin{tabular}{lllll}
$\begin{array}{l}\text { Incredere } \\
\text { colegi }\end{array}$ & $.41^{* *}$ & 1 & & \\
$\begin{array}{l}\text { Id. cu organizatia } \\
\text { Stare de bine }\end{array}$ & $.72^{* *}$ & $.46^{* *}$ & 1 & \\
\hline
\end{tabular}

${ }^{* *}$ Corelatiile sunt semnificative la pragul de .01 (2-tailed).

Verificarea ipotezelor:

1. Leadershipul transformațional prezice identificarea $\mathrm{cu}$ organizația.

Printr-o regresie liniară simplă, leadershipul transformațional a prezis semnificativ identificarea cu organizaţia $(b=1.87,=F(1,128)=139.01, p<$ $.001), \mathrm{R}^{2}=.52$, ceea ce confirma prima ipoteză a studiului.

2. Leadershipul transformațional prezice încrederea cu colegii Printr-o regresie liniară simplă, leadershipul transformaţional a prezis semnificativ identificarea cu organizația $(b=.214,=F(1,128)=25.946, p<$ $.001), \mathrm{R}^{2}=.17$, ceea ce confirma a doua ipoteză a studiului.

3. Relaţia dintre leadershipul transformaţional şi identificarea cu organizaţia este mediată de încrederea faţă de colegii de muncă.

Pentru a se stabili dacă relaţia dintre leadershipul transformaţional (LT) şi identificarea cu organizația (IO) este mediată de încrederea cu colegii (IC) se apelează la modelul 4 din macroul PROCESS. Rezultatele arată un $\mathrm{F}(2,127)=79.469, \mathrm{p}<001 \mathrm{R}^{2}=.556\left(\mathrm{R}^{2}\right.$ change $\left.=0.36\right) ; \mathrm{LT}: \mathrm{b}=1.65 \mathrm{t}$ $(127)=9.82<.001 ; \mathrm{IC}: \mathrm{b}=1.09 \mathrm{t}(127)=3.18<00$, cu efect indirect dat de bootstrap (5000) CI $[.74,1.96]$, cu un interval care nu cuprinde 0 , ceea ce înseamnă că efectul de mediere este semnificativ, rezultat întărit de testul Sobel $Z=4.05, p<001, k^{2}=.28$. În concluzie, încrederea în colegi mediază parțial relația, efectul direct fiind semnificativ la $\mathrm{p}<001$, adăugând increment leadershipului transformațional asupra identificării cu organizația, ceea ce ne validează a treia ipoteză de cercetare.

4. Leadershipul transformațional prezice starea de bine psihologică.

Printr-o regresie liniară simplă, leadershipul transformațional a prezis semnificativ starea de bine psihologică $(b=.526,=F(1,128)=9.30, p<$ $.01), \mathrm{R}^{2}=.068$, ceea ce confirmă a patra ipoteză a studiului. 
5. Relaţia dintre leadershipul transformaţional şi starea psihologică de bine este mediată de identificarea cu organizaţia.

Modelul 4 din PROCESS F $(2,127)=8.82, \mathrm{p}<001 \mathrm{R}^{2}=.13\left(\mathrm{R}^{2}\right.$ change $=$ $0.054 \mathrm{p}<0.01) ; \mathrm{IC}-\mathrm{b}=.26 \mathrm{t}(127)=2.80 \mathrm{p}<.01 ; \mathrm{LT}-\mathrm{b}=.03 \mathrm{t}(127)=.14 \mathrm{p}<$ .88 ceea ce indică o mediere totală indicată de efectul indirect bootstrap (5000) CI [.06,.91], cu un interval care nu cuprinde 0 , ceea ce înseamnă că efectul de mediere este semnificativ, rezultat întărit de testul Sobel $\mathrm{Z}=$ 2.71, p <001, $\mathrm{SE}=.18$., ceea ce confirma ipoteza numărul 5 a studiului.

6. Încrederea în colegii prezice starea de bine psihologică.

Printr-o regresie liniară simplă, încrederea cu colegii a prezis semnificativ starea de bine psihologică $(b=.06,=F(1,128)=8.01, p<.01)$, $\mathrm{R}^{2}=.052$, ceea ce confirmă ipoteza numărul 6 a studiului.

7. Încrederea în colegii prezice identificarea cu organizaţia.

Printr-o regresie liniară simplă, încrederea cu colegii a prezis semnificativ starea de bine psihologică $(b=.09,=F(1,128)=35.90, p<$ $.001), \mathrm{R}^{2}=.21$, ceea ce confirmă ipoteza numărul 6 a studiului.

8. Relația dintre încrederea cu colegii şi starea de bine psihologică este mediată de identificarea cu organizația.

Modelul 4 din PROCESS F $(2,127)=9.48, \mathrm{p}<001 \mathrm{R}^{2}=.13\left(\mathrm{R}^{2}\right.$ change $=$ $0.071 \mathrm{p}<0.005) ; \mathrm{IO}-\mathrm{b}=.23 \mathrm{t}(127)=3.22 \mathrm{p}<.001 ; \mathrm{IC}-\mathrm{b}=.039 \mathrm{t}(127)=1.08$ $\mathrm{p}<.28$ ceea ce indică $\mathrm{o}$ mediere totală sugerat de efectul indirect bootstrap (5000) CI [.21,1.00], cu un interval care nu cuprinde 0, ceea ce înseamnă că efectul de mediere este semnificativ, rezultat întărit de testul Sobel $\mathrm{Z}=2.80, \mathrm{p}<005, \mathrm{SE}=.19$., ceea ce confirma ipoteza numărul 8 a studiului.

9. Relaţia dintre leadershipul transformaţional şi starea psihologică de bine este mediată de încrederea faţă de colegii de muncă.

Efectul indirect bootstrap (5000) CI [-.0005,.012], cu un interval care cuprinde 0 , ceea ce indică faptul că relația de mediere nu este semnificativă, rezultat întărit de testul Sobel $\mathrm{Z}=1.65, \mathrm{p}<.10, \mathrm{SE}=.08$, ceea ce infirmă ipoteza numărul 9 a studiului.

10. Relaţia dintre leadershipul transformațional şi subfactorii stării de bine psihologice: sens în viaţă, controlul mediului şi 
relaţii pozitive $\mathrm{cu}$ ceilalți este mediată de identificarea cu organizaţia.

Identificarea $\mathrm{cu}$ organizaţia a mediat semnificativ relaţia dintre leadershipul transformaţional şi sens în viaţă cu un interval de efect indirect Bootstrap .086 SE = .036 [.016,.158], Sobel Z = 2.4, p<.01, SE = .03.; controlul mediului cu un interval de efect indirect Bootstrap $10 \mathrm{SE}=$ $.048[.014, .20]$, Sobel $\mathrm{Z}=2.3, \mathrm{p}<.01, \mathrm{SE}=.04$; relaţii pozitive cu ceilalţi cu un interval de efect indirect Bootstrap .09 SE $=.038[.016, .16]$, Sobel Z = 2.4, $\mathrm{p}<.01, \mathrm{SE}=.03$

11. Relaţia dintre încrederea cu colegii şi subfactorii stării de bine psihologice: autoacceptarea, relații pozitive cu ceilalţi şi dezvoltare personală este mediată de identificarea cu organizaţia

Identificarea $\mathrm{cu}$ organizația a mediat semnificativ relaţia dintre încrederea în colegii de muncă şi autoacceptare cu un interval de efect indirect Bootstrap $.09 \mathrm{SE}=.04$ [.012,.18], Sobel $\mathrm{Z}=2.3, \mathrm{p}<.02, \mathrm{SE}=.03$; relații pozitive cu ceilalți cu un interval de efect indirect Bootstrap .08 SE $=.04[.014, .17]$, Sobel $\mathrm{Z}=2.1, \mathrm{p}<.03, \mathrm{SE}=.03$; dezvoltare personală cu un interval de efect indirect Bootstrap .07 SE $=.03[.014, .16]$, Sobel $\mathrm{Z}=2.1, \mathrm{p}$ $<.02, \mathrm{SE}=.03$.

Având în vedere corelaţiile între toate variabilele şi efectul mediator a două dintre acestea, dorim să rulăm un model cu două mediatoare pentru starea de bine psihologică. Acest lucre a fost demarat folosind modelul 6 din macroul PROCESS. Surprinzător, intervalele de încredere bootstrap pentru ruta Leadership -> Încredere -> Identificare -> SBP a fost semnificativă pentru efectul total de .52 CI [.08,.98], modelul fiind semnificativ la $\mathrm{F}(3,126)=6.2, \mathrm{p}<.001), \mathrm{R}^{2}=.13$. Ruta de interacțiune doi (Leadership -> Identificare $->\mathrm{SBP}$ ) fiind calea prin care cea mai multă variantă este explicate la .38 CI [.005,.77]. Intervalul de încredere se apropie de 0 iar la rularea succesivă a analize, intervalele suferă schimbări în output datorită proprietăților limitate a eşantionului cules.

Singura relație de mediere din modelul 6 care nu a fost semnificativă a fost efectul încrederii cu colegii asupra relaţiei dintre leadershipul transformațional şi starea de bine psihologică. Având în vedere faptul că încrederea cu colegii de muncă şi leadershipul 
transformațional a fost mediat de total de identificarea cu organizaţia în relaţia cu factori diferiţi ale stării de bine psihologic, acest lucru poate indica căi diferite prin care aceşti doi factori acţionează asupra stării de bine precum şi posibile faţete diferite ale identificării cu organizaţia ce acționează în acesta relație cu fiecare variabilă luată separat.

\section{Implicații teoretice și practice}

Scopul cercetării de faţă a fost de a stabili mecanismele socialcognitive, mai exact, leadershipul transformaţional şi încrederea cu colegii de muncă, ce pot contribui la identificarea cu organizaţia a angajaților. Apelând la paradigmă socială, prin teoria socială a identităţii şi teoria categorizării sinelui, am stabilit pentru prima dată în literatură, din cunostiintele autorului, importanța conturării unei identități sociale, prin identificarea individului cu organizaţia, pentru starea de bine psihologică generală al lui Ryff (1989). Mai exact, studiul prezent indică faptul că leadership-ul transformaţional şi încrederea în colegi au un efect asupra stării noastre psihologice de bine iar aceste relaţii sunt mediate în totalitate de identificarea cu organizaţia. Mai mult decât atât, leadershipul tranformational şi încrederea în colegii de muncă au prezis fațete diferite ale stării de bine prin medierea cu identificarea cu organizație, sugerând faptul că acestea au acționat cel mai probabil prin incremente diferite ale identificării cu organizaţia.

Autonomia nu a fost prezisă de nici una din cele două relaţii de mediere, acest factor cel mai probabil fiind determinat de factori structurali decât factori contextuali (flexibilitatea orelor de muncă, lucrul de acasă, dificultatea obţinerii zilelor de concediu şi posibilitatea înlocuirii în cazul în care apar probleme personale, etc.).

Având în vedere importanța muncii, unui scop şi direcţii, identificării individului cu ceva mai mare decât acesta, nevoia de apartenenţa şi de identificare, posibilitatea de a colabora cu mai mulţi oameni în vederea atingerii unui scop supraordonat şi schimburile de resurse, informații şi sprijin afectiv pe care organizaţiile le pot oferii, este curios faptul că literatura de specialitate nu a aruncat o privire la starea de bine eudaemonica în relație $\mathrm{cu}$ identificarea $\mathrm{cu}$ organizația şi alte concepte de sine derivate din apartenența la organizație dar sperăm că această lucrare va stimula noi interese de cercetare în această direcție. 


\section{Directii viitoare}

Studiile viitoare ar trebui să controleze nivelul de abstractizare prin care individul se identifică cu organizaţia, mai exact, acesta integrează valori şi principii universale (leadershipul transformaţional) sau îşi satisface nevoia de apartenenţa la un grup/organizaţie (prin coeziunea grupului). Această relaţie ar putea fi mediată de efectul de dizolvare a sinelui, mai exact absorbirea sau imersarea sinelui la niveluri de abstractizare maximale, de obicei prezente la persoanele autoactualizate, care şi-au definit scopul în viaţa printr-o cauză supraordonată umanităţii sau cele care sunt într-o stare de flow.

De asemenea, se recomandă investigarea suplimentară a unei posibile suprapuneri conceptuale între leadershipul tranformațional și identificarea cu organizația, a instrumentelor de măsurare ale acestor concepte, precum și stabilirea relaţiilor si a direcțiilor cauzale.

\section{Limite}

O limită a studiului este determinată de faptul că nu s-a folosit o scală divizată în factori a leadershipului transformațional care ar fi ajutat definirea rutelor posibile prin care individul integrează aspectele organizaționale în conceptele de sine (având în vedere varianța foarte mare pe care leadershipul transformațional l-a împărtăşit cu identificarea cu organizația). Chiar mai mult, ar putea integra conceptul nou apărut în literatură de specialitate a leadershipului autentic, ce integrează tipologiile de leader carismatic, transformaţional şi etic (Avolio \& Gardner, 2005). De asemenea, nici scală de identificare cu organizaţia nu a oferit o perspectivă mai granulata a subfactorilor acestui construct. Poate una dintre cele mai mari limite ale sudiului este vârsta medie a eșantionului care a fost compus predominant din tineri $(\mathrm{M}=27.5)$ iar efectul leadershipului cu siguranţă a avut de suferit (în literatură, relaţia dintre leadershipul transformaţional şi starea de bine psihologică este mult mai pregnantă). Designul studiului a fost unul de tip cross secțional ceea ce nu ne permite să derivăm relații de cauzalitate. 


\section{Bibliografie}

Arnold, K. A., Turner, N., Barling, J., Kelloway, E. K., \& McKee, M. C. (2007). Transformațional leadership and psychological wellbeing: the mediating role of meaningful work. Journal of occupational health psychology, 12(3), 193.

Ashforth, B. E., Harrison, S. H., \& Corley, K. G. (2008). Identification in organizations: An examination of four fundamental questions. Journal of management, 34(3), 325-374.

Avolio, B. J., \& Gardner, W. L. (2005). Authentic leadership development: Getting to the root of positive forms of leadership. The leadership quarterly, 16(3), 315-338.

Bass, B. M. (1998). Transformational leadership: Industrial, military, and educational impact. Mahwah, NJ: Erlbaum.

Bass, B. M., \& Riggio, R. E. (2006). Transformational leadership (2nd ed.). Mahwah, NJ: Erlbaum.

Cheney, G. (1983). On the various and changing meanings of organizational membership: Field study of organizational identification. Communication Monographs, 50, 342-362.

Daniel, D., \& Aurora, S. (2017). Tratat de psihologie pozitiva, Iasi: Polirom.

Faul, F., Erdfelder, E., Lang, A. G., \& Buchner, A. (2007). G* Power 3: A flexible statistical power analysis program for the social, behavioral, and biomedical sciences. Behavior research methods, 39(2), 175-191.

Ferres, N., Connell, J., \& Travaglione, A. (2004). Co-worker trust as a social catalyst for constructive employee attitudes. Journal of Managerial Psychology, 19(6), 608-622.

Haslam, S. A., Jetten, J., Postmes, T., \& Haslam, C. (2009). Social identity, health and well-being: An emerging agenda for applied psychology. Applied psychology: an international review, 58(1), 1-23.

Hayes, A. F. (2016). The PROCESS macro for SPSS and SAS. Preluat de pe http://www.afhayes.com/public/processv31.zip.

Howell, J. M., \& Higgins, C. A. (1990). Champions of technological innovation. Administrative science quarterly, 317-341.

IBM Corp. Released 2011. IBM SPSS Statistics for Windows, Version 20.0. Armonk, NY: IBM Corp. 
Iliescu, D., Popa, M., \& Dimache, R. (2016). Adaptarea românească a Setului Internațional de Itemi de Personalitate: IPIP-Ro. Psihologia Resurselor Umane, 13(1), 83-112.

Jung, D. I., Chow, C., \& Wu, A. (2003). The role of transformațional leadership in enhancing organizational innovation: Hypotheses and some preliminary findings. The leadership quarterly, 14(4-5), 525-544.

Kállay, É., \& Rus, C. (2014). Psychometric properties of the 44-item version of Ryff's Psychological Well-Being Scale. European Journal of Psychological Assessment, 30(1), 15-21.

Kelloway, E. K., Turner, N., Barling, J., \& Loughlin, C. (2012). Transformational leadership and employee psychological wellbeing: The mediating role of employee trust in leadership. Work $\mathcal{E}$ Stress, 26(1), 39-55.

Koh, W. L., Steers, R. M., \& Terborg, J. R. (1995). The effects of transformational leadership on teacher attitudes and student performance in Singapore. Journal of organizational behavior, 16(4), 319-333.

Lee, D., \& Stajkovic, A. D. (2005). Interpersonal trust and emotion as predictors of cooperation in work teams. Paper presented at the Academy of Management Meeting, Honolulu, HI.

Nielsen, K., Yarker, J., Randall, R., \& Munir, F. (2009). The mediating effects of team and self-efficacy on the relationship between transformational leadership, and job satisfaction and psychological well-being in healthcare professionals: A crosssectional questionnaire survey. International journal of nursing studies, 46(9), 1236-1244.

Podsakoff, P. M., MacKenzie, S. B., Moorman, R. H., \& Fetter, R. (1990). Transformational leader behaviors and their effects on followers' trust in leader, satisfaction, and organizational citizenship behaviors. The leadership quarterly, 1(2), 107-142.

Rafferty, A. E., \& Griffin, M. A. (2004). Dimensions of transformational leadership: Conceptual and empirical extensions. The leadership quarterly, 15(3), 329-354.

Rotter, J. B. (1967). A new scale for the measurement of interpersonal trust. Journal of personality, 35(4), 651-665. 
Ryan, R. M., \& Deci, E. L. (2001). On happiness and human potentials: A review of research on hedonic and eudaimonic well-being. Annual review of psychology, 52(1), 141-166.

Ryff, C. D. (1989). Happiness is everything, or is it? Explorations on the meaning of psychological well-being. Journal of personality and social psychology, 57(6), 1069.

Ryff, C. D., \& Keyes, C. L. M. (1995). The structure of psychological wellbeing revisited. Journal of personality and social psychology, 69(4), 719.

Ryff, C. D., Singer, B. H., \& Love, G. D. (2004). Positive health: connecting well-being with biology. Philosophical Transactions of the Royal Society B: Biological Sciences, 359(1449), 1383.

Stevenson, W. B., \& Gilly, M. C. (1991). Information processing and problem solving: The migration of problems through formal positions and networks of ties. Academy of Management Journal, 34(4), 918-928.

Tan, H. H., \& Lim, A. K. (2009). Trust in coworkers and trust in organizations. Journal of Psychology, 143(1), 45-66.

Thoits, P. A. (2012). Role-identity salience, purpose and meaning in life, and well-being among volunteers. Social Psychology Quarterly, 75(4), 360-384.

Turner, J. C., Hogg, M. A., Oakes, P. J., Reicher, S. D., \& Wetherell, M. S. (1987). Rediscovering the social group: A self-categorization theory. Basil Blackwell.

Wrightsman, L. S. (1966). Personality and attitudinal correlates of trusting and trustworthy behaviors in a two-person game. Journal of Personality and Social Psychology, 4(3), 328.

Zand, D. E. (1972). Trust and managerial problem solving. Administrative science quarterly, 229-239. 